\title{
Herbigation* in a Vineyard through a Microjet Irrigation System
}

\author{
J.C. Fourie \\ Viticultural and Oenological Research Institute, Private Bag X5026, 7600 Stellenbosch, Republic of South Africa
}

Submitted for publication: April 1988

Accepted for publication: May 1988

Keywords: Herbicides, herbigation, chemigation, weed control, weedicides, grapevines

\begin{abstract}
The control of a variety of weeds by one post-emergence and five pre-emergence herbicides applied through a microjet irrigation system was determined. Oxadiazon and simazine gave good control of the weed species present in the trial. Napropamide controlled the different grass species effectively, but did not control the broadleaf weeds. A combination of chlorsulfuron and metsulfuron methyl, in the ratio 3:1, controlled two grasses and one broadleaf weed effectively. Oryzalin controlled three of the predominent grass species effectively, but did not control the broadleaf weeds. It was found that herbigation with any of the five pre-emergence herbicides mentioned, can be utilized commercially to control susceptible weeds on medium textured soils in South African vineyards. A comparative study with simazine showed that herbigation through microjet irrigation systems can replace tractor boom sprayers as an application technique on medium textured soils. In the case of a microjet irrigation system with the emitters mounted at $3 \mathrm{~m}$ intervals, the microjets should be situated on top of the irrigation line and the pressure in the system maintained at 200 $\mathrm{kPa}$ to ensure an efficient application. The post-emergence weed control by paraquat dichloride was unacceptable.
\end{abstract}

Conventional applications of herbicides in South African vineyards are done mainly by tractor boom sprayers. However, applications of herbicides through irrigation systems (herbigation), hold great promise. According to Threadgill (1981), herbigation increases crop production efficiency by reducing costs for equipment, labour and fuel, especially for farmers who already have the equipment to inject fertilizer into the irrigation system.

The feasibility of herbigation was well proven by previous research. Various researchers achieved effective weed control with different combinations of irrigation systems and herbicides (Uda \& Morimoto, 1977; Ogg, 1980; Banks \& Dowler 1984). Fisher et al. (1985) found that oryzalin (3,5-dinitro- $\mathrm{N}^{4} \mathrm{~N}^{4}$-diethylpropionamide), a mixture of simazine [2-chloro-4,6-di(ethylamino)-1,3,5triazine] and oryzalin as well as a mixture of simazine and napropamide [2-( $\propto$-naphthoxy)-N',N'-diethylpropionamide] gave good weed control when applied through a low-volume sprinkler system. Lange et al. (1974) also achieved good weed control with a combination of simazine and oryzalin. Another effective combination was simazine plus oxadiazon [5-tert-butyl3-(2,4-dichloro-5-isopropoxyphenyl)-1,3,4-oxadiazol-2one]. The weed control efficiency of napropamide was more constant than that of the other herbicides over the 9-month evaluation period which was probably due to its resistance to leaching.

Researchers reported dissimilar results when they compared the weed control efficiency of herbicides applied through an irrigation system and with a conventional sprayer. The performance of alachlor $(\propto$-chloro2',6'-diethyl-N-mehtoxymethylacetanilide and atrazine [2-chloro-4-(ethylamino)-6-(isopropylamino)-S-triazine] was identical for the two methods of application (Robison \& Mulliner, 1972; Fischbach \& Martin, 1976). Weed control obtained with butylate (S-ethyl di- isobutylthiocarbamate), EPTC (S-ethyl dipropylthiocarbamate) and vernolate [S-propyl dipropyl (thiocarbamate)] however, was slightly better with the conventional applications than with the sprinkler applications (Fischbach \& Martin, 1976). Oren and Israeli (1977) found that a mixture of bromacil (5-bromo-3-sec-butyl6-methyluracil) and diuron [3-(3,4-dichlorophenyl)-1,1dimethylurea] gave better and longer control of the predominant weeds when applied through the irrigation system. King, Miller and Smith (1980) found that chlorthal dimethyl (dimethyl-2,3,5,6-tetrachloroterephthalate) applied through a sprinkler irrigation system was slightly more effective than when applied by a conventional sprayer. Trifluralin $(2,6$, dinitro-N,N- dipropyl-4-trifluoromethylaniline) was much less effective when applied through a sprinkler system than when applied conventionally (Smith, Berner \& Walter, 1973; Ogg, 1976; Ogg, 1980).

Various factors influence the efficiency of herbigation. Crutchfield, Clark and Wiese (1977) showed that about $85 \%$ of the trifluralin applied in irrigation water was lost by evaporation before it reached the soil surface. Under the same conditions, loss of atrazine was only $10 \%$. These results explain why atrazine can be applied through sprinkler systems and efforts to do the same with trifluralin have failed. According to Ogg (1986), herbicides with relatively low vapour pressure such as alachlor, atrazine and metribuzin (4-amino-6tert-butyl-4,5-dihydro-3-methylthio-1,2,3-triazin-5-

one) controlled weeds equally well when applied through sprinklers or sprayed conventionally, whereas herbicides with relatively high vapour pressures such as EPTC, vernolate and trifluralin are less effective when applied through sprinklers. Some pre-emergence herbicides are less effective when applied conventionally, because the spray droplets dry rapidly and the herbicides are partly adsorbed on the soil particles of the sur-

Paper presented at the 11th congress of the South African Society for Enology and Viticulture, Cape Town, November 5-6, 1987

The author expresses his sincere thanks and appreciation to the staff of the Soil Science Section for their technical assistance.

${ }^{*}$ Registered trade name of Stauffer Chemical Company, USA. 
face soil. During the subsequent irrigation the herbicide must first be desorbed before it can move into the top soil layer. Where herbigation is used, the herbicide is moved into the soil without intermediate drying, thus making it more available for pre-emergence weed control (Horowitz \& Bucsbaum, 1978).

Effective distribution of the herbicides depends on an even water distribution which was defined as the Coefficient of Uniformity (CU) (Christiansen, according to Vories \& Von Bernuth, 1986). According to Woodward (1959), the following factors primarily influence the water distribution pattern of a system namely 1) the spacing of the emitters and laterals; 2) the emitter size and 3) the water pressure in the system. Whenever the spacing of the emitters is changed, the extent of the overlap from adjacent emitters changes. Therefore, a decrease in the spacing of the emitters usually increases the $\mathrm{CU}$ if all the other variables are held constant (Vories \& Von Bernuth, 1986). Increasing the pressure, increases the wetting diameter of emitters. This tends to give more uniform distribution patterns. Low $\mathrm{CU}$ values indicate an incorrect combination of emitter size, operating pressure and spacing (Woodward, 1959). Wind is the environmental factor that most reduces the uniformity of application. Woodward (1959) stated that the CU decreased as wind speed increased. According to Ogg et al. (1983), herbicides should not be applied through a solid set irrigation system when wind velocities exceed $12 \mathrm{~km} / \mathrm{h}$.

In most cases, crop tolerance to a herbicide is the same whether it is applied conventionally or through an irrigation system (Robison \& Mulliner, 1972; Fishbach \& Martin, 1976; Horowitz \& Bucsbaum, 1978). Oryzalin, oxadiazon, oxyfluorfen (2-chloro- $\propto \propto \propto$-trifluoro-ptolyl-3-ethoxy-4-nitrophenyl ether) and metolachlor [2chloro-6'-ethyl-N-(2-methoxy-1-methylethyl) acet-Otoluidide] with or without simazine applied by means of herbigation resulted in $9-19 \%$ less injury to three container-grown ornamental species and 6-13\% better control of Digitaria sanguinalis than the conventional spray applications (Caviness, Talbert \& Klingaman, 1983). A factor affecting phytotoxicity in herbigation is the rinse factor. According to Ogg (1981) very little herbicide remains on the leaves of crop plants due to rinsing, which explains why seedling lucerne (Medicago sativa) is more tolerant to bromoxynil (3,5 dibromo-4-hydroxybenzonitrile) applied through sprinklers than bromoxynil applied with a conventional sprayer. Oren and Israeli (1977) found that a rinse period of ten minutes after application of a bromacil and diuron mixture through a solid set irrigation system is needed to prevent damage to the leaves of 4-year-old grapefruit trees.

In the case of the post-emergence herbicides, Dowler (1982) found that acifluorfen [5-(2-chloro- $\propto \propto \propto$-trifluoro-p-tolyoxy)-2-nitrobenzoic acid] and sethoxydim $[( \pm)-2-[1-($ ethoxyiminobutyl)]-5-(2-ethylylthio) propyl]-3-hydroxy-cyclohex-2-enone] showed moderate to good activity when applied by means of a centre pivot irrigation system. Ogg (1981) found that bromoxynil and a mixture of bromoxynil and MCPA (4-chloro-2methylphenoxyacetic acid) applied to both wheat (Triticum aestivum) and lucerne through herbigation did not control the weeds as effectively as when applied conventionally. Robison and Mulliner (1972) concluded that herbigation was not appropriate for foliageactive herbicides because these are washed off the leaves.

When stationary sprinkler systems are used, most herbicides should be applied during the first part of the irrigation period (Callihan et al., 1978). According to Oren and Israeli (1977) a minimum of 15 minutes of application time is required to ensure an even distribution of the herbicide used. Successful weed control through herbigation as well as crop tolerance towards a herbicide depends greatly upon the amount of water applied after the herbicide has passed through the irrigation system (Ogg et al., 1983; Ogg, 1986). Phatak (1982) found that metham sodium (sodium N-methyldithiocarbamate) was the most effective when applied with $6,4 \mathrm{~mm}$ and $12,7 \mathrm{~mm}$ irrigation water on a Lakeland sand by means of solid set overhead sprinklers. In the case of atrazine as well as a mixture of butylate and r-25788 (S-ethyl diisobutylthiocarbamate), Todd and Klocke (1984) obtained the most effective weed control with applications of a $19 \mathrm{~mm}$ and $25 \mathrm{~mm}$ irrigation on a fine sandy soil. Callihan and Leino (1979) found that EPTC and vernolate applied through solid set sprinklers on a silt loam controlled wheat (used as a bioassay plant) better when followed by $13 \mathrm{~mm}$ or $25 \mathrm{~mm}$ of water.

Although herbigation was researched well in the case of sprinkler irrigation systems, very little research was done with low volume systems. It was, therefore, necessary to evaluate the feasibility of herbigation through a microjet irrigation system as an application technique in South African vineyards. Five pre-emergence herbicides and one post-emergence herbicide were included in the study to determine their weed control efficiency when applied through a microjet irrigation system.

\section{MATERIALS AND METHODS}

\section{Experiment 1: Water distribution pattern}

Irrigation lines were mounted $3 \mathrm{~m}$ apart on a wire $450 \mathrm{~mm}$ above the soil surface with the microjets installed $3 \mathrm{~m}$ apart. In this study microjets with a $280^{\circ}$ and $360^{\circ}$ wetting pattern delivering $32 \mathrm{l} / \mathrm{h}$ were evaluated. The microjets on adjacent irrigation lines were installed in alternating positions. To determine the water distribution pattern, catch cans were placed $300 \mathrm{~mm}$ apart over the whole area wetted by a microjet $\left(9 \mathrm{~m}^{2}\right)$. The microjets were operated at water pressures of $100 \mathrm{kPa}, 150 \mathrm{kPa}$ and $200 \mathrm{kPa}$. The first series of water distribution patterns were determined with the microjets situated on top of the irrigation line, whereupon the whole process was repeated with the irrigation line in the inverted position. Each treatment was replicated five times. The treatments were evaluated for surface wetting (\% coverage) and the variation in the water distribution pattern which was expressed as the Coefficient of Uniformity.

\section{Experiment 2: Evaluation of different pre-emergence herbicides}

This investigation was carried out in a seven-year-old Vitis vinifera $\mathrm{cv}$ Pinotage vineyard grafted on 99 Richter rootstock. The vines were growing on a medium tex- 
tured Clovelly soil, with a clay content of $18 \%$, and were trained onto a slanted trellis system. The irrigation system used for this experiment consisted of irrigation lines with a diameter of $20 \mathrm{~mm}$, mounted $3 \mathrm{~mm}$ apart on a wire $450 \mathrm{~mm}$ above the soil surface. Microjets $\left(360^{\circ}\right)$ delivering $32 \mathrm{l} / \mathrm{h}$ were mounted $3 \mathrm{~m}$ apart on top of the irrigation line with the microjets on adjacent lines in alternating positions. Each plot consisted of an area of $108 \mathrm{~m}^{2}$ and was replicated four times in a randomized block design. The treatments were a control (no herbicide application) and five pre-emergence herbicides, namely simazine ( $3 \mathrm{~kg} / \mathrm{ha})$, oxadiazon $(1,2 \mathrm{~kg} / \mathrm{ha})$, napropamide $(2,7 \mathrm{~kg} / \mathrm{ha})$, oryzalin $(2,3 \mathrm{~kg} / \mathrm{ha})$ and a mixture of chlorsulfuron [2-chloro-N(4-methoxy-6methyl-1,3,5-triazin-2-yl) aminocarbonyl benzene sulfonamide] and metsulfuron methyl [methyl 2-[[[] (4methoxy-6-methyl-1,3,5-triazin-2-yl) amino] carbonyl] amino] -sulfonyl] benzoate] at a dosage of $25 \mathrm{~g}$ and $8 \mathrm{~g} / \mathrm{ha}$ respectively. These herbicides were injected into the microjet irrigation line by means of a diaphragm pump during the first 20 minutes of an irrigation with the pressure in the system at $200 \mathrm{kPa}$. The herbicides were applied with $20 \mathrm{~mm}$ of irrigation water at the flowering stage of the vines. Ten weed species (or bioassay plants) were sown one day before herbigation to ensure a good weed stand in the experimental plots. For the duration of the experiment, $25 \mathrm{~mm}$ of irrigation water was applied weekly. The rainfall over the 90 days in which the weed control efficiency was monitored amounted to $73 \mathrm{~mm}$. The dry mass per $\mathrm{m}^{2}$ was determined and the number of weeds per $\mathrm{m}^{2}$ counted 30,60 and 90 days after herbigation to determine the weed stand and the efficiency of the different treatments. Simultaneously the vines were monitored visually for any phytotoxicity symptoms on the leaves. Additionally, all species representing more than $5 \%$ of the spectrum were identified and their control by the different herbicides expressed as a percentage of the control treatment.

These measurements were taken during both the $1985 / 86$ and $1986 / 87$ season.

Experiment 3: Comparison of herbigation vs conventional method

In this experiment simazine $(3 \mathrm{~kg} / \mathrm{ha})$ was applied during November by means of a tractor boom sprayer (an application volume of $500 \mathrm{l} / \mathrm{ha}$ ) and a microjet irrigation system as described in Experiment 2, respectively. Each treatment covered an area of $420 \mathrm{~m}^{2}$. From each treatment 10 randomly selected sites $\left(1 \mathrm{~m}^{2}\right)$ were chosen on which the dry mass and the number of weeds per $\mathrm{m}^{2}$ were determined 90 days after the application date.

\section{Experiment 4: Evaluation of a foliage-active-herbicide}

The efficiency of paraquat dichloride applied early September (before budburst) by means of a microjet irrigation system as a post-emergence treatment on $\mathrm{Se}$ cale cereale, established as a cover crop in the working rows of the vineyard used in Experiment 2, was determined. The paraquat dichloride $(1 \mathrm{~kg} / \mathrm{ha})$ was injected into the microjet irrigation system by means of a diaphragm pump while the pressure in the system was 200 $\mathrm{kPa}$. Injection times of 9,10 and 11 minutes were used and evaluated as three different treatments. The effi- ciency of the applications were evaluated visually , 14 days after the application and expressed as a percentage of the control.

\section{RESULTS AND DISCUSSION}

Experiment 1: With the irrigation line in the inverted position, neither the $280^{\circ}$ nor the $360^{\circ}$ microjet could give a $100 \%$ coverage of the measured area at the three water pressures applied (Table 1), which is unacceptable for total weed control by means of herbigation. With the microjet situated on top of the irrigation line, a $100 \%$ coverage of the area was achieved at all the given pressures. The Coefficient of Uniformity (CU) of the $280^{\circ}$ microjet was constantly higher than that of the $360^{\circ}$ microjet (Table 1 ). This could be attributed to the fact that the $360^{\circ}$ microjet consisted of twelve orifices distributing the water as twelve separate jets, whereas the $280^{\circ}$ microjet delivered the water through two orifices that fanned the water over the wetting area. For both types of microjets used in the study, the CU improved with an increase in the water pressure. The highest CU's were achieved with the $280^{\circ}$ microjet at a pressure of $200 \mathrm{kPa}$ followed by the $280^{\circ}$ microjet at 150 $\mathrm{kPa}$ and the $360^{\circ}$ microjet at a pressure of $200 \mathrm{kPa}$. A CU of $80 \%$ and higher is acceptable for field applications (Griffin, 1978). Therefore herbigation through a microjet system should be done with the microjets mounted on top of the irrigation line and the water pressure at $200 \mathrm{kPa}$. This study showed that the water pressure in a solid set irrigation system affected the water distribution of the emitters, which is contrary to what was found for a centre pivot irrigation system (Banks \& Dowler, 1984).

TABLE 1

Water distribution and Coefficient of Uniformity of microjet emitters, mounted on the irrigation line at $3 \mathrm{~m}$ intervals determined at three different pressures.

\begin{tabular}{|c|c|c|c|c|}
\hline \multirow{2}{*}{ Nozzle } & \multirow{2}{*}{$\begin{array}{c}\text { Pressure } \\
(\mathrm{kPa})\end{array}$} & $\begin{array}{c}\text { Emitters } \\
\text { inverted }\end{array}$ & \multicolumn{2}{|c|}{$\begin{array}{c}\text { Emitters in vertical } \\
\text { positions }\end{array}$} \\
\cline { 3 - 5 } & & $\%$ coverage & $\%$ coverage & CU $^{*}$ \\
\hline $280^{\circ}$ & 200 & 43 & 100 & 90 \\
& 150 & 32 & 100 & 88 \\
& 100 & 24 & 100 & 68 \\
\hline $360^{\circ}$ & 200 & 70 & 100 & 80 \\
& 150 & 70 & 100 & 74 \\
& 100 & 57 & 100 & 53 \\
\hline
\end{tabular}

*Not determined for emitters underneath the line because of inadequate coverage

Experiment 2: The efficiency of the five pre-emergence herbicides is illustrated in Tables 2 to 4 . The results obtained, showed the same tendencies for both seasons and therefore only the results of the $1986 / 87$ season are presented in this paper. Thirty days after the herbicides were applied, the stand of the weeds (compared on a dry mass basis) in all the treatments was no higher than $11 \%$ of that of the control (Table 2). Sixty days after application the weed stand in the simazine, oxadiazon and napropamide treatments still did not exceed $4,5 \%$ 
TABLE 2

Effect of herbicides on weed stand per $\mathrm{m}^{2}$ at different periods after application through microjets.

\begin{tabular}{|c|c|c|c|c|c|c|}
\hline \multirow{3}{*}{ Treatments } & \multicolumn{6}{|c|}{ Days after application } \\
\hline & \multicolumn{2}{|c|}{30} & \multicolumn{2}{|c|}{60} & \multicolumn{2}{|c|}{90} \\
\hline & $\begin{array}{l}\text { Dry mass } \\
(\mathrm{g})\end{array}$ & $\begin{array}{l}\% \text { of the } \\
\text { Control }\end{array}$ & $\begin{array}{l}\text { Dry mass } \\
(\mathrm{g})\end{array}$ & $\begin{array}{l}\% \text { of the } \\
\text { Control }\end{array}$ & $\begin{array}{l}\text { Dry mass } \\
(\mathrm{g})\end{array}$ & $\begin{array}{l}\% \text { of the } \\
\text { Control }\end{array}$ \\
\hline Control & 5,06 & 100 & 22,37 & 100 & 44,19 & 100 \\
\hline Oryzalin & 0,54 & 10,7 & 5,06 & 22,6 & 8,21 & 18,6 \\
\hline Napropamide & 0,02 & 0,4 & 1,01 & 4,5 & 1,77 & 4 \\
\hline Oxadiazon & 0,12 & 2,4 & 0,33 & 1,5 & 2,16 & 4,9 \\
\hline Simazine & 0,02 & 0,4 & 0,86 & 3,9 & 1,95 & 4,4 \\
\hline $\begin{array}{l}\text { Chlorsulfuron/ } \\
\text { Metsulfuron methyl }\end{array}$ & 0,56 & 11 & 17,08 & 76,4 & 36,72 & 83,1 \\
\hline $\begin{array}{l}\mathrm{D} \text { value } \\
(\mathrm{P} \leqslant 0,01)\end{array}$ & 2,49 & - & 14,04 & - & 16,75 & - \\
\hline
\end{tabular}

of the control while the stand in the oryzalin and chlorsulfuron/metsulfuron methyl treatments was $22,6 \%$ and $76,4 \%$, respectively. Ninety days after application, the tendency in all the treatments remained the same.

The number of weeds per $\mathrm{m}^{2}$ was lower than $7 \%$ of the control for the simazine, oxadiazon and napropamide treatments up to 90 days after the application of the herbicides (Table 3). For the oryzalin treatment the number of weeds varied between $7,6 \%$ and $19,4 \%$ of the control. For the chlorsulfuron/metsulfuron methyl treatment it varied between $42 \%$ and $73 \%$. In the control plots, the weed population did not increase from the second ( 60 days) to the third ( 90 days) evaluation. This might be due to the inhibitory effect of the established weeds on the germination of new weeds.

Seven weed species (two broadleaf weeds and five grasses) were found to be representative of the weed population in the control plots (Table 5). Simazine gave excellent control of all the weed species present except for Vicia sativa which was controlled moderately at the 60 day period but good to excellent at the 30 day and 90 day periods. The reason for this is not clear. Setaria italica, Eragrostis curvula and Digitaria smutsii were controlled excellently by oxadiazon for a period of 90 days. This herbicide gave good control of the Secale, Medicago and Rhyncheletum species up to 90 days after application. Vicia sativa was controlled moderately at the 90 day evaluation. Both napropamide and oryzalin gave excellent control of the Digitaria, Eragrostis and Rhyncheletum species. The control of Secale cereale by the napropamide treatment was good up to 90 days after application, whereas the control of Medicago sati$v a$ was unacceptable after sixty days. The herbicide did not control Vicia sativa at all. Neither of the broadleaf weeds was controlled sufficiently by oryzalin. Initial control of the Secale and Setaria species by the oryzalin treatment was excellent, but the weeds broke through after a period of 30 days. The chlorsulfuron/metsulfuron methyl mixture gave excellent control of the Seta-

TABLE 3

The effect of different herbicides on weed number per $\mathrm{m}^{2}$ at different periods after application through microjets.

\begin{tabular}{|c|c|c|c|c|c|c|}
\hline \multirow{3}{*}{ Treatments } & \multicolumn{6}{|c|}{ Days after application } \\
\hline & \multicolumn{2}{|c|}{30} & \multicolumn{2}{|c|}{60} & \multicolumn{2}{|c|}{90} \\
\hline & $\begin{array}{l}\text { Weeds } \\
\text { per } \mathrm{m}^{2}\end{array}$ & $\begin{array}{l}\% \text { of the } \\
\text { Control }\end{array}$ & $\begin{array}{l}\text { Weeds } \\
\text { per } \mathrm{m}^{2}\end{array}$ & $\begin{array}{l}\% \text { of the } \\
\text { Control }\end{array}$ & $\begin{array}{l}\text { Weeds } \\
\text { per } \mathrm{m}^{2}\end{array}$ & $\begin{array}{l}\% \text { of the } \\
\text { Control }\end{array}$ \\
\hline Control & 134 & 100 & 499 & 100 & 444 & 100 \\
\hline Oryzalin & 22 & 16,4 & 38 & 7,6 & 86 & 19,4 \\
\hline Napropamide & 3 & 2,2 & 18 & 3,6 & 31 & 7 \\
\hline Oxadiazon & 4 & 3,0 & 5 & 1 & 16 & 3,6 \\
\hline Simazine & 1 & 0,7 & 6 & 1,2 & 11 & 2,5 \\
\hline $\begin{array}{l}\text { Chlorsulfuron/ } \\
\text { Metsulfuron methyl }\end{array}$ & 94 & 70 & 211 & 42 & 324 & 73 \\
\hline $\begin{array}{l}\text { D value } \\
(P \leqslant 0,01)\end{array}$ & 74 & - & 129 & - & 115 & - \\
\hline
\end{tabular}


TABLE 4

The control of different weed species by five herbicides at different periods after application through microjets.

\begin{tabular}{|c|c|c|c|c|c|c|c|c|c|c|c|c|c|c|c|}
\hline \multirow{4}{*}{ Weed species } & \multicolumn{15}{|c|}{ Control } \\
\hline & \multicolumn{3}{|c|}{ Simazine } & \multicolumn{3}{|c|}{ Oxadiazon } & \multicolumn{3}{|c|}{ Napropamide } & \multicolumn{3}{|c|}{ Oryzalin } & \multicolumn{3}{|c|}{$\begin{array}{c}\text { Chlorsulfuron/ } \\
\text { metsulfuron } \\
\text { methyl }\end{array}$} \\
\hline & \multicolumn{3}{|c|}{$\begin{array}{l}\text { Days after } \\
\text { application }\end{array}$} & \multicolumn{3}{|c|}{$\begin{array}{c}\text { Days after } \\
\text { application }\end{array}$} & \multicolumn{3}{|c|}{$\begin{array}{l}\text { Days after } \\
\text { application }\end{array}$} & \multicolumn{3}{|c|}{$\begin{array}{l}\text { Days after } \\
\text { application }\end{array}$} & \multicolumn{3}{|c|}{$\begin{array}{l}\text { Days after } \\
\text { application }\end{array}$} \\
\hline & 30 & 60 & 90 & 30 & 60 & 90 & 30 & 60 & 90 & 30 & 60 & 90 & 30 & 60 & 90 \\
\hline Medicago sativa & A & $\mathrm{A}$ & A & A & $\mathrm{A}$ & B & A & B & $\mathrm{E}$ & $\mathrm{D}$ & B & $E$ & A & A & A \\
\hline Vicia sativa & B & $\mathrm{C}$ & A & A & B & $\mathrm{C}$ & $E$ & $E$ & $\mathrm{E}$ & $\mathrm{D}$ & $E$ & E & $E$ & E & $E$ \\
\hline Rhyncheletum repens & A & A & A & A & A & B & A & A & A & A & A & A & A & A & A \\
\hline Digitaria smutsii & A & A & A & A & A & A & A & A & $\mathrm{A}$ & A & A & A & $\mathrm{C}$ & $\mathrm{E}$ & $E$ \\
\hline Secale cereale & $\mathrm{A}$ & B & $\mathrm{A}$ & $\mathrm{A}$ & A & B & A & B & B & A & $\mathrm{D}$ & $\mathrm{E}$ & $\mathrm{C}$ & $E$ & $\mathrm{E}$ \\
\hline Eragrostis curvula & A & $\mathrm{A}$ & A & A & A & A & $\mathrm{A}$ & A & $\mathrm{A}$ & A & A & A & $E$ & $E$ & $E$ \\
\hline Setaria italica & $\mathrm{A}$ & A & A & A & A & A & A & A & A & A & $\mathrm{E}$ & $E$ & B & A & A \\
\hline
\end{tabular}

$\mathrm{A}=$

$\mathrm{B}=$

$\mathrm{C}=$

$\mathrm{D}=$

$\mathrm{E}=$
Excellent weed control

Good weed control

Moderate weed control

Poor weed control

Unacceptable weed control

$\begin{array}{ll}= & 90 \%-100 \% \text { control } \\ = & 80 \%-90 \% \text { control } \\ = & 70 \%-80 \% \text { control } \\ = & 60 \%-70 \% \text { control } \\ = & 0 \%-60 \% \text { control }\end{array}$

ria, Rhyncheletum and Medicago species for a period of 90 days after application. However, the control of the other weed species was unacceptable.

When evaluating the results as a whole, it is clear that simazine and oxadiazon gave acceptable control of all the weed species. Napropamide gave excellent control of the grass species, but failed to control the broadleaf weeds to the same extent. Oryzalin did not control the two broadleaf weeds and although all the grass species were controlled initially, only three were controlled eventually. The chlorsulfuron/metsulfuron methyl mixture controlled the same number of weed species as the oryzalin treatment. The much weaker performance of the mixture in comparison to oryzalin is due to the fact that the weed species controlled by oryzalin comprised $70 \%$ of the weed population. Unfortunately it is especially the Digitaria and Eragrostis species that give problems in vineyards under irrigation.

No phytotoxicity symptoms occurred on the vine leaves in any of the herbicide treatments even though the herbicides were applied in an actively growing vineyard.

Experiment 3: Simazine controlled weeds equally well when applied through microjet irrigation system or applied conventionally (Table 5). This result indicates

\section{TABLE 5}

Weed control by simazine applied with a tractor boom sprayer and a microjet irrigation system.

\begin{tabular}{|l|c|c|}
\hline $\begin{array}{c}\text { Application } \\
\text { method }\end{array}$ & $\begin{array}{c}\text { Weed dry mass } \\
\text { in } \mathrm{g}\left(\mathrm{g} / \mathrm{m}^{2}\right)\end{array}$ & $\begin{array}{c}\text { Number of } \\
\text { weeds } / \mathrm{m}^{2}\end{array}$ \\
\hline Tractor boom sprayer & 7,94 & 78 \\
\hline Microjet irrigation system & 6,36 & 43 \\
\hline Statistical significance & $\mathrm{NS}$ & $\mathrm{NS}$ \\
\hline
\end{tabular}

that the microjet irrigation systems can replace tractor boom sprayers as an application method for pre-emergence herbicides.

Experiment 4: None of the paraquat dichloride treatments had any effect on the cover crop (data not shown). It seems that the stand of the cover crop was too dense for sufficient penetration by the scorching agent. Furthermore the herbicide was diluted to such an extent by the irrigation water that it could not function properly. This finding supports the conclusion of Robison and Mulliner (1972) that herbigation is not suitable for foliage-active herbicides.

\section{CONCLUSIONS}

Simazine, oxadiazon, napropamide, oryzalin and a mixture of chlorsulfuron/metsulfuron methyl controlled susceptible weeds effectively when applied through the microjet irrigation system without damaging the vines, although applied during the active growth stage of trellised vines. The results indicate that herbigation can replace the tractor boom sprayers as an application technique on medium textured and possibly also on heavy soils as far as pre-emergence herbicides are concerned. Where solid set irrigation systems are concerned, the water pressure in the system during application greatly influences the water distribution. To make sure that the herbicide is applied efficiently, the irrigation system should have a CU of at least $80 \%$. This can be achieved by mounting the emitters on top of the irrigation line at the correct spacings and by maintaining a suitable water pressure in the system during application.

Post-emergence weed control with paraquat dichloride applied by herbigation is unacceptable and the conventional method should still be used for post-emergence herbicides.

For the purpose of this study the herbicides were applied at the dosage normally used for the conventional application method. Research must be done to deter- 
mine if a lower dosage can be used for herbigation without a loss of efficiency. The mobility of the pre-emergence herbicides in the different soil types should be investigated to determine the appropriate amount of irrigation water to obtain good weed control with the lowest dosage possible.

\section{LITERATURE CITED}

BANKS, P.A. \& DOWLER, C.C., 1984. Application efficiency of herbicides by irrigation systems. Southern Weed Sci. Soc. Proc. 37, 395.

CALLIHAN, R.H. \& LEINO, P.W., 1979. Effect of sprinkler irrigation water volume for incorporation of thiocarbamate and metribuzin herbicides. Proc. Western Soc. Weed Sci. 32, 66-67.

CALlIHAN, R.H., McMASTER, G.M., LEINO, P.W., SLAWINSKA, H. \& CORSINI, D., 1978. Potato herbicide application through sprinklers. Proc. Western Soc. Weed Sci. 31, 159.

CAVINNES, D.M., TALBERT, R.E. \& KLINGAMAN, G.L., 1983. Herbigation and spray applications of herbicides on container ornamentals. Southern Weed Sci. Soc. Proc. 35, 140.

CRUTCHFIELD, D.A., CLARK, R.N. \& WIESE, A.F., 1977. Deposition of atrazine and trifluralin with sprinkler irrigation. Southern Weed Sci. Soc. Proc. 30, 428.

DOWLER, C.D., 1982. New technology in herbigation. In : Young, J.R. Summer, D.R. (eds.). Proc. 2nd Nat. Symp. on Chemigation, Tifton, Georgia, August 1982. University of Georgia Rural Development Centre, Tifton, Georgia, pp 28-34.

FISCHBACH, P.E. \& MARTIN, A.R., 1976. Application of herbicides through a center pivot sprinkler. In : Monaco, T.J. (ed.). Weed Sci. Soc. Am. Abstr., Denver, Colorado, February 1976, No. 247. Weed Science Society of America, Champaign Illinois.

FISCHER, B.B., GOLDHAMER, D.A., BABB, T. \& KJEL GREN, R., 1985. Weed Control under drip and low volume sprinkler irrigation. California Agriculture 39, 24-25.

GRIFFIN, S.B., 1978. Computer programming solid set systems. ASAE Paper No. 78-2012, ASAW, St. Joseph, Michigan.

HOROWITZ, M. \& BUCSBAUM, H., 1978. Application of herbicides through irrigation. Proc. Mediterranean Herbicide Symp. 2, 48-62.

KING, J.W., MILLER, E.M. \& SMITH, H.R., 1980. Herbigation to control crabgrass, goosegrass and annual bluegrass. Southern Weed Sci. Soc. Proc. 33, 340.

LANGE, A., ALJIBURY, F., FISCHER, B., HUMPHREY, W. \& OTTO, H., 1974. Weed control under drip irrigation in orchard and vineyard crops. In : March, A.W. (ed.). Proc. 2nd Int. Drip
Irrigation Congress, San Diego, California. Department of Soil Science and Agriculture Engineering, University of California, Riverside, California, pp 422-424.

OGG, A.G. (JR), 1976. Application of herbicides through sprinklers. Proc. Western Soc. Weed Sci. 29 59-73.

OGG, A.G. (JR), 1980. A sprinkler system for research on applying herbicides in irrigation water. Weed Science 28, 201-203.

OGG, A.G. (JR), 1981. Conventional versus sprinkler application of herbicides. In : Ramsey, H. (ed.). Proc. 31st Ann. Conf. Wash ington State Weed Assoc., Yakima, Washington, November 1981. Washington State Weed Association, Yakima, Washington, pp 45-57.

OGG, A.G. (JR), 1986. Applying herbicides in irrigation water - a review. Crop Protection 5(1), 53-65.

OGG, A.G. (JR), DOWLER, C.C., MARTIN, A.R., LANGE, A.H. \& HEIKES, P.E., 1983. Application of herbicides through irrigation systems. Item No. AD-FO 2280. Co-operative Extension, United States Department of Agriculture, Washington, D.C, 8 pp.

OREN, Y. \& ISRAELI, E., 1977. Herbicide application through irrigation systems (herbigation) in citrus. Proc. Int. Soc. Citriculture 1, 152-154.

PHATAK, S.C., 1982. Effect of metham sodium applied through overhead irrigation systems on weed control and yield of vegetables. In : Young, J.R. \& Summer, D.R. (eds.). Proc. 2nd Nat. Symp. on Chemigation, Tifton, Georgia, August 1982. University of Georgia Rural Development Centre, Tifton, Georgia, pp 23-27.

ROBISON, L.R. \& MULLINER, H.R., 1972. Sprinkler applied herbicides do a good job in Nebraska tests. Weeds Today 3, 6-7.

SMITH, D.T., BERNER, R.C. \& WALTER, J.R., 1973. Nitralin and trifuralin incorporated by rainfall and irrigation. Weed Research 13, 359-366.

THREADGILL, E.D., 1981. Why chemigate. In : Young, J.R. (ed.) Proc. 1st Nat. Symp. on Chemigation, Tifton, Georgia, August 1981. University of Georgia Rural Development Centre, Tifton, Georgia, pp 1-6.

TODD, R. \& KLOCKE, N.L., 1984. Sprinkler irrigation applied herbicides for sandbur control on a sandy soil. North Central Weed Cont. Conf. Proc. 39, 4.

UDA, H. \& MORIMOTO, J., 1977. Studies on the multi-purpose utilization of sprinkler irrigation systems in citrus groves of Wakayama prefecture. Proc. Int. Soc. Citriculture 1, 93-98.

VORIES, E.D. \& VON BERNUTH, R.D., 1986. Single nozzle sprinkler performance in wind. Transactions of the ASAE. 29(5), 1325-1330.

WOODWARD, G.O., 1959. Sprinkler irrigation. Second Edition. Sprinkler Irrigation Association, 1318 Second Street, Suite 27, Santa Monica, California. 